\title{
Intellectual Property Rights, Technology Transfer and Exports in Developing Countries
}

\author{
Lei Yang
}

Keith E. Maskus

Second revision: July 2008

\begin{abstract}
We develop a model to analyze one mechanism under which stronger intellectual property rights (IPR) protection may improve the ability of firms in developing countries to break into export markets. A Northern firm with a superior process technology chooses either exports or technology transfer through licensing as its mode of supplying the Southern market, based on local IPR policy. Given this decision, the North and South firms engage in Cournot competition in both markets. We find that stronger IPR would enhance technology transfer through licensing and reduce the South firm's marginal production cost, thereby increasing its exports. Welfare in the South would rise (fall) if that country has high (low) absorptive capacity. Excessively strong IPR diminish competition and welfare, however. Adding foreign direct investment as an additional channel of technology transfer sustains these basic messages.
\end{abstract}

JEL Classification: F14, L13, O1, O34

Keywords: Intellectual Property Rights, Technology Transfer, Exports

Lei Yang: School of Accounting and Finance, The Hong Kong Polytechnic University, Hong Kong; aflyang@inet.polyu.edu.hk.

Corresponding author: Keith E. Maskus, Department of Economics, UCB 256, University of Colorado, Boulder CO 80309; 303-492-7588; keith.maskus@ colorado.edu.

We thank Yongmin Chen, Gordon Hanson, James Markusen, Walter Park and two referees for helpful comments and suggestions. 


\section{Introduction}

Since 1995 many developing countries have reformed their laws governing intellectual property rights (IPR). Reforms in IPR are commonly presumed by trade economists to raise imitation costs, reduce access to global information and place firms in developing countries at a competitive disadvantage in global markets (Helpman, 1993; Lai and Qiu, 2004). However, one essential purpose of IPR is to reduce the costs of technology transfer (Maskus, 2004). Indeed, empirical evidence supports the view that multinational firms expand technology flows through greater foreign direct investment (FDI) and licensing as local patent rights are improved (Smith 2001; Branstetter, et al, 2005).

By expanding access to international technologies, strengthened IPR could improve the export performance of recipient firms, a possibility that has been little studied to date. In this paper we provide a model of contracting and technology transfer that illuminates one such mechanism. Specifically, we analyze a model of two-country competition between a Northern firm and an unaffiliated Southern firm, where the former may choose to provide cost-reducing technical information to the latter through licensing or FDI. We find conditions under which greater transfers are made in equilibrium under stronger patents and the consequent effect on exports of the Southern firm. Welfare in the Southern country increases if its firm has high absorptive ability, but could fall if it has a weak capacity to implement new technology.

In contrast to our strategic approach, the theoretical literature generally has set out general-equilibrium, North-South product-cycle models among atomistic firms competing dynamically. Helpman (1993) and Glass and Saggi (1999) assumed stronger IPR would raise imitation costs, tending to diminish technology flows and global innovation. Lai (1998) 
noted that innovation could be enhanced if FDI is the form of technology transfer. Yang and Maskus (2001) found that patent reforms would both raise imitation costs and reduce the costs of technology licensing, with the latter encouraging greater information transfer and innovation in equilibrium.

These insights are valuable. However, to make these dynamic models tractable the authors forego analysis of strategic interactions among firms. The primary advantage of our approach is to permit detailed analysis of the microeconomic tradeoffs involved in contracting in response to IPR changes. Our bargaining framework explicitly considers strategic choices among imitation, licensing, and FDI at various ranges of patent strength, generating a rich menu of tradeoffs and welfare calculations that cannot readily be analyzed in the more general context. Of course, the partial-equilibrium Cournot context within which we operate also makes strong assumptions for tractability. ${ }^{1}$ Thus, we comment later on how the results would vary with alternative assumptions.

Empirical evidence in several developing countries suggests that investing in technology is important for entering export markets (Hasan and Raturi, 2001). Key sources of such investment are imports of technology and linkages to multinational firms (Kumar and Siddharthan, 1993). However, this literature has paid little attention to the combination of IPR, technology transfer and trade in order to establish a linkage between IPR and exports. A recent exception is Branstetter, et al, (2007), whose empirical analysis found an increase in export intensity of local affiliates of multinational firms after IPR policy changes. Again, none of these papers considered the detailed mechanisms under which IPR reforms could expand technology transfer and exports.

\footnotetext{
${ }^{1}$ Vishwashrao (1994) is an early example of a strategic model of IPR and technology transfer.
} 
As empirical motivation for our framework, within which patent reforms may encourage more technology transfer through unaffiliated licensing, with a subsequent boost to exports, consider two recent histories from East Asia. South Korea engineered a major strengthening of its patent laws from 1988 to 1995 (LaCroix and Kawaura, 1996), increasing its measured patent index by 47 percent, from 2.65 to 3.89 , between 1985 and $1995 .^{2}$ Taiwan (Chinese Taipei) made substantial reforms in 1986 and 1994 (Diallo, 2003), raising its index by 152 percent, from 1.26 to 3.17 , over the same period. South Korea's licensing payments to unaffiliated U.S. firms rose from \$38 million in 1987 to $\$ 717$ million in 1995 , reaching $\$ 1.686$ billion in 2005. Taiwan's licensing payments to unaffiliated U.S. firms rose from $\$ 17$ million in 1986 to $\$ 267$ million in 1996 , reaching $\$ 1.165$ billion in 2006 . Finally, South Korea’s merchandise exports rose from $\$ 28.5$ billion in 1985 to $\$ 99.5$ billion in 1995 , reaching $\$ 284.4$ billion in 2005 . Taiwan's exports similarly rose from $\$ 33.4$ billion in 1985 to $\$ 128.4$ billion in 1995 , reaching $\$ 223.7$ billion in $2006 .^{3}$

\section{The Model}

We study the effects of IPR on export development in an oligopolistic setting. Consider a world economy of two regions, North and South. Assume that at most one firm in each country can profitably produce the good. We denote these firms by $\mathrm{N}$ and $\mathrm{S}$. Both firms produce a single homogenous good and compete in Cournot fashion. Assume also that the two markets are segmented, in the sense that firms can charge a different price in each market.

\footnotetext{
${ }^{2}$ This measure is the well known Ginarte-Park index, explained in Ginarte and Park (1997).

${ }^{3}$ Sources for these data include the on-line WTO statistics database, World Bank World Development Indicators (CD-ROM), and U.S. Department of Commerce (2007).
} 


\section{2a. Consumption}

Let the utility functions in both regions be quadratic in the good we study, with an additive term for a second composite good. If $A$ and $B$ represent the market size of North and South, respectively, the inverse-demand functions for our good are

$$
p_{N}=A-q_{N} ; p_{S}=B-q_{S} .
$$

We assume that market sizes are sufficiently greater than marginal costs to ensure positive production.

\section{2b. Decision on Mode of Supply}

Only the $\mathrm{N}$ firm engages in prior $\mathrm{R} \& \mathrm{D}$, which achieves proprietary technological knowledge embedded in the production process for its good. It can retain production at home and export the good to market S, risking loss of its knowledge through imitation, or transfer the technology through licensing. ${ }^{4}$ The choice depends on the absorptive capacity of the licensee, market size, the threat of imitation, and the legal protection of technology.

We assume that codified knowledge (e.g., blueprints and formulas) can be imitated by S, but tacit knowledge (e.g., know-how and information gained from experience) cannot. Imitation of codified knowledge is costly and can be achieved under the export mode through product inspection, reverse engineering, or trial and error. Imitation permits $\mathrm{S}$ to avoid paying license fees but the reduction in its production costs is less than it would be with licensing because the firm cannot acquire know-how this way.

$\mathrm{N}$ may instead offer to license production rights to $\mathrm{S}$. In this event the licensing contract specifies a lump-sum fee and $\mathrm{S}$ is able to produce the good at reduced marginal cost with partial access to know-how. If $\mathrm{S}$ accepts the licensing contract it would have no

\footnotetext{
${ }^{4}$ We extend the model to technology transfer through FDI in the next section.
} 
incentive to imitate. Thus, its problem is a tradeoff between the license fee and imitation costs, with different impacts on marginal production costs.

Our specification of a lump-sum license fee without per-unit royalties captures the empirical reality that a large portion of technology contracts in developing countries have this feature. For example, Vishwasrao (2007) assembled data on all foreign technology licensing agreements entered into by manufacturing firms, unaffiliated with the licensors, in India between 1989 and 1993. Over the period 1991-1993, there were 968 contracts with only lump-sum fees, amounting to 45 percent of all licensing deals.

\section{2c. Costs and Production}

We assume that labor is the only factor of production and that N's marginal production cost is $c_{N}$. Before any imitation or licensing, let S's marginal production cost be $c_{S}$, which is greater than $c_{N}$ because the firm has no knowledge of N's improved

technology. A key parameter, the absorptive ability of $\mathrm{S}$, is denoted by $a \in[0,1]$, where an increase in $a$ indicates higher learning capacity. This capacity is exogenous and given by such characteristics of the South market as education level and infrastructure. Because a stronger learning capacity would permit more efficient production, we assume that imitation reduces marginal cost by more, the greater is $a$. The reduced cost is $c_{s}-m(a), m^{\prime}>0$.

Let $k \in[0,1]$ be the strength of IPR in the South. Parameter $k$ is 1 when patent protection is highest and 0 if patents are absent. Denote by $I(k, a)$ the S firm's imitation cost. Stronger IPR make it harder for S to imitate N's product. Indeed, as IPR protection approaches its maximum the costs of legally imitating around a patent become quite high. 
Thus, we suppose that imitation will not occur beyond some less-than-full level of protection..$^{5}$ At the same time, a higher absorptive capacity makes it easier for $\mathrm{S}$ to imitate.

There are costs of transferring technology through licensing. Two components of these costs involve setting enforceable contract terms and shifting codified knowledge. These costs typically fall as Southern IPR are tightened because enforceable patents and trade secrets reduce contracting problems under asymmetric information and limit the need for $\mathrm{N}$ to masque its proprietary knowledge (Taylor, 1994; Yang and Maskus, 2001). The third component of transfer cost is ensuring that local partners gain the know-how needed to produce efficiently. We assume that these costs increase with the proportion of know-how transferred, which we capture by parameter $x \in[0,1]$. Thus, let licensing incur a transfer cost $F(x, k)=\varphi+G(x, k)$, where $\varphi$ is a fixed transfer cost and variable cost $G$ decreases with the strength of IPR and increases with the proportion of know-how transferred. ${ }^{6}$ This transfer cost $F$ is borne by both partners and enters only their payoff functions through a reduction in joint surplus. It does not directly affect production profits. If $\mathrm{S}$ accepts the licensing contract, the technology is transferred and its marginal production cost becomes $c_{s}-r(x, a)$. Here $r(x, a)$ is the advantage to $\mathrm{S}$ of accepting the license and learning know-how. We posit that this cost reduction is positively related to both S's absorptive ability and the proportion of know-how that $\mathrm{N}$ transfers, and is concave in

\footnotetext{
${ }^{5}$ One proof below relies on a convexity assumption that $\frac{\partial^{2} I}{\partial k^{2}}<0$, though this cost can get high enough to deter imitation.

${ }^{6}$ We assume that $\frac{\partial^{2} G(x, k)}{\partial x \partial k}<0$.
} 
both $x$ and $a$. Finally, assume that $c_{S}>c_{N}>c_{S}-m(a) \geq c_{S}-r(x, a)$. Thus, either imitation or licensing reduces S's marginal cost below N's but the decline is greater in the latter case. ${ }^{7}$

Nash bargaining determines the lump-sum license fee $L$, which must be paid to gain production rights and know-how. Let $\tau$ be the bargaining power of $\mathrm{N}$ and $1-\tau$ that of $\mathrm{S}$. This parameter determines the shares of joint surplus from sales under licensing. S's bargaining power reflects its lower labor cost and knowledge of local market conditions and N's power reflects the uniqueness of its technology.

\section{2d. Decision Structure under Varying North Import Policies}

In this game there are two players, firms $\mathrm{S}$ and $\mathrm{N}$. Initially, $\mathrm{N}$ is the global (twocountry) monopoly and S may imitate the technology through reverse engineering. Northern import policy related to IPR is important. The North may choose to permit imports from the $\mathrm{S}$ firm, even if that firm imitates the $\mathrm{N}$ technology without a license. However, such imitation could violate the patent issued in the North and $\mathrm{N}$ could direct its government to bar imitative imports. ${ }^{8}$ We initially consider the case without import blockage and then analyze competition subject to this constraint.

The timing of the game without blockage is as follows. In the first stage, given the Southern IPR policy, N chooses either to export to the South, risking imitation, or offer a license. If $\mathrm{N}$ exports, in the second stage $\mathrm{S}$ can choose to imitate, incurring a cost, or do nothing. If $\mathrm{S}$ imitates competition emerges in the third stage and the firms simultaneously choose quantities in both markets. If $\mathrm{S}$ does not imitate, $\mathrm{N}$ remains the global monopoly.

\footnotetext{
${ }^{7}$ That is, we assume that $m(a)=r(0, a)$, so that imitation is identical to the absence of know-how transfer.

${ }^{8}$ Such is the policy in the United States under Section 337of the 1930 Tariff Act, as amended.
} 
If $\mathrm{N}$ offers a license to $\mathrm{S}$, the firms bargain over the fee. If the negotiation succeeds, technology is transferred and both firms simultaneously choose optimal quantities produced. Otherwise, S can choose to imitate or not enter the market.

\section{2.e Equilibrium Analysis}

We begin by analyzing the equilibrium where $\mathrm{N}$ exports. Initially suppose that $\mathrm{S}$ chooses to imitate. Then the respective final-stage maximization problems under export are

$$
\begin{aligned}
& \operatorname{Max} \Pi_{N E}=\left(A-q_{N N}^{E}-q_{S N}^{E}\right) q_{N N}^{E}+\left(B-q_{N S}^{E}-q_{S S}^{E}\right) q_{N S}^{E}-c_{N}\left(q_{N N}^{E}+q_{N S}^{E}\right) \\
& \operatorname{Max} \Pi_{S E}=\left(A-q_{N N}^{E}-q_{S N}^{E}\right) q_{S N}^{E}+\left(B-q_{N S}^{E}-q_{S S}^{E}\right) q_{S S}^{E}-c_{S E}\left(q_{S N}^{E}+q_{S S}^{E}\right)-I(k, a)
\end{aligned}
$$

Here the $E$ superscript refers to the exports equilibrium and $c_{S E}=c_{S}-m(a)$. Solving for the optimal quantities, equilibrium profits under exporting are given by

$$
\begin{gathered}
\Pi_{N E} *=\frac{A^{2}-4 A c_{N}+2 A c_{S E}+8 c_{N}{ }^{2}-8 c_{N} c_{S E}+2 c_{S E}{ }^{2}+B^{2}-4 B c_{N}+2 B c_{S E}}{9} \\
\Pi_{S E} *=\frac{A^{2}+2 A c_{N}-4 A c_{S E}+2 c_{N}{ }^{2}-8 c_{N} c_{S E}+8 c_{S E}{ }^{2}+B^{2}-4 B c_{S E}+2 B c_{N}}{9}-I(k, a)
\end{gathered}
$$

If $\mathrm{S}$ chooses not to imitate and produce, its profit is 0 . Let superscript $N B$ refer to no Northern import blockage and define $k=\bar{k}^{N B}$ as the IPR level at which imitation cost just offsets production profit and $\Pi_{S E} *=0 .{ }^{9} \mathrm{~S}$ will imitate when $k<\bar{k}^{N B}$, with profit declining in $k$, and will not enter when $k>\bar{k}^{N B}$.

Next, if $\mathrm{N}$ offers a license and the negotiation fails, the equilibrium is the same as that under export. If licensing is offered and the negotiation succeeds, $\mathrm{N}$ could have two choices in principle after transferring its process technology. It could continue producing and

\footnotetext{
${ }^{9}$ By assumption this level is below full IPR protection. Later we analyze a functional form where this assumption holds.
} 
compete with $\mathrm{S}$ in both markets. Alternatively, it could commit not to produce, leaving $\mathrm{S}$ as a monopolist. However, in our game structure this situation cannot survive as the equilibrium. ${ }^{10}$ The reason is that the license fee is a one-time transaction paid prior to the production stage, so that a commitment not to compete is not credible. We therefore analyze the case where a license payment is made but both firms produce.

Maximizing the relevant profit functions in this case shows that the $\mathrm{N}$ firm's equilibrium production profits increase with the reduction in $\mathrm{S}$ marginal costs, sustaining the incentive to license technology. ${ }^{11}$ In the negotiation stage, $\mathrm{N}$ decides how much know-how will be transferred to $\mathrm{S}$ under the contract. The $\mathrm{N}$ profit equals the sum of the license fee and production profit under successful licensing. Its maximization problem is ${ }^{12}$

$$
\operatorname{Max}_{x} \Pi_{N L}=\Pi_{N E} *+\tau\left[S_{1}(x, a)+I(k, a)-F(x, k)\right]
$$

where $S_{1}>0$ is an expression involving market sizes, marginal costs, and reductions in costs from imitation and licensing. The first term is N's profit under exports and the second term represents its share of joint surplus (in brackets), which $\mathrm{N}$ maximizes through its choice of $x$. Because $S_{l}$ is positive, this joint surplus rises in $k$. We denote the first-order condition of (6) as $f\left(x^{*}, k, a\right)$. The equilibrium know-how transferred satisfies

$$
f\left(x^{*}, k, a\right)=\left[\frac{2}{9} A+\frac{2}{9} B+\frac{16}{9} c_{N}-\frac{20}{9}\left(c_{S}-r\left(x^{*}, a\right)\right)\right] \frac{\partial r\left(x^{*}, a\right)}{\partial x}-\frac{\partial F\left(x^{*}, k\right)}{\partial x}=0
$$

Consider briefly the situation in which the Northern government blocks imitative imports but freely permits imports of goods produced by S under license. By restricting one competitive outlet $\left(q_{S N}^{E}=0\right)$, the S firm's tradeoffs are altered. Performing the relevant

\footnotetext{
${ }^{10}$ We demonstrate this fact in a mathematical appendix available on request.

${ }^{11}$ From this point forward, profit functions are suppressed to save space.

${ }^{12}$ Determination of the license fee is in the mathematical appendix.
} 
substitutions and computing profit functions, we find a threshold IPR level $\bar{k}^{B}$ above which S does not imitate and $\mathrm{N}$ remains a monopoly in both markets with blocking. Below that level, $\mathrm{N}$ monopolizes its own market but the firms compete in South.

In the bargaining game under licensing, N's profit expression is the sum of its exports under blocking-aided monopoly (its reservation value) and its share of the joint surplus, where $\mathrm{S}$ can now export to North. We can show that the licensing equilibrium becomes more likely the greater the reduction in S's marginal cost. Further, the larger is North market size, the less likely is licensing (import blockage sustains the monopoly in a large market) but the larger is the South market the more likely is licensing. Thus, under some circumstances, duopoly profit under licensing can dominate monopoly profit under export with imitation risk, even where the North government blocks imitative imports.

\section{The Impacts of IPR Reform}

In this section we study the effect of a stronger patent regime on the extent of knowhow licensed, exports, and the choice between export and licensing.

\section{3a. Extent of Know-how Transferred}

Suppose that licensing is chosen. Differentiating expression (7) shows that

$$
\frac{d x^{*}}{d k}>0 \text { if } A+B+8 c_{N}-10 c_{S L}>\phi\left(x^{*}, a\right), \text { where } \phi\left(x^{*}, a\right)=\frac{10\left[\frac{\partial r\left(x^{*}, a\right)}{\partial x}\right]^{2}}{-\frac{\partial^{2} r\left(x^{*}, a\right)}{\partial x^{2}}}
$$

This result demonstrates that stronger patent rights increase the amount of know-how transferred under large joint market size, high marginal cost in $\mathrm{N}$, and low marginal cost in $\mathrm{S}$ post-transfer. We can similarly show that the amount of know-how transferred increases 
with the absorptive ability of the $\mathrm{S}$ firm under the same conditions. These results hold under any licensing equilibrium, regardless of North's import-blockage policy.

\section{3b. Southern Exports}

Suppose first that exports with imitation pertain at low $k$ range. Our assumption that a rise in $k$ affects $\mathrm{S}$ imitation cost but not marginal cost implies that imitative exports are insensitive to policy changes in this region. Consider next the role of IPR on exports under successful licensing. We saw that know-how rises with IPR under large joint market size and large difference in marginal costs. Under these circumstances, tighter patents reduce production cost in S, shifting outward that firm's reaction function and expanding exports to the N market. Similar analysis finds that stronger IPR would increase S's domestic production and imports from $\mathrm{N}$ would fall. However, in the case of small joint market size and small difference in marginal costs, $\mathrm{S}$ activities would decline.

The intuition is that stronger patents in the South increase (decrease) the marginal benefit (marginal cost) of transferring know-how, raising the amount transferred. Also, there are fixed costs of technology transfer and it requires large market sizes to guarantee that the total surplus is positive. Under such circumstances, stronger technology protection would make the $\mathrm{S}$ firm more competitive in the international market.

\section{3c. N Firm's Export or Licensing Decision}

Assume imitative imports are not banned. Working back to the first stage of the game, $\mathrm{N}$ compares export profit with licensing profit in deciding the mode of entry. We determine $k_{l}$, the threshold value of IPR that induces licensing as the equilibrium outcome. This occurs where the profit from licensing just equals that from export, or the joint surplus in brackets in equation (6) is zero. Under our assumptions this joint surplus at $k=0$ is 
negative because the technology transfer costs are high and S's productivity gain is small, despite the low imitation cost. Further, the joint surplus at $k=1$ is positive. Finally, because this surplus is non-decreasing in $k$, the threshold value lies between zero and one.

There is no solution for this value under our general functional forms for changes in costs of technology transfer, production and imitation. We therefore adopt specific functional forms that conform to our assumptions and calculate the threshold value of $k .{ }^{13}$ With this specification, $\mathrm{N}$ licensing profits follow an inverse- $\mathrm{U}$ shape in the amount of knowhow transferred. These profits are maximized at some $x^{*}<1$, implying incomplete knowhow transfer. Further, licensing profit rises throughout as patents are strengthened as long as licensing is the equilibrium. However, this relationship is concave so that the profit gain under licensing diminishes as $k$ rises.

When patent protection gets sufficiently high S's imitation cost would be prohibitive. In that case, $\mathrm{N}$ exports to South and achieves a monopoly profit that exceeds its profit under duopoly with licensing. We find that monopoly is the equilibrium in this unblocked case if

IPR exceeds a threshold value $\bar{k}^{N B}$, which depends on imitation costs and absorptive ability. In the case where North blocks imitative imports, however, the corresponding IPR level at which S chooses not to imitate is $\bar{k}^{B}$. It is straightforward to show that $\bar{k}^{B}<\bar{k}^{N B}<1$. In short, if the North blocks imitative imports the altered payoffs deter licensing and sustain a full $\mathrm{N}$ monopoly at a lower level of Southern patent rights.

As noted above, we define $k_{l}$ as the critical IPR value that induces a shift from exporting with imitation risk to licensing, assuming no import blockage. Similarly, we define $k_{2}$ as this critical IPR value when there is import blockage. It can be shown that $k_{1}<$

${ }^{13}$ These forms are listed in the mathematical appendix. 
$k_{2}$, so that the North policy of banning imports deters imitation up to a higher level of Southern patent protection.

In Figure 1 the horizontal lines represent N's export profits and the other curve represents profits from licensing. ${ }^{14}$ Thus, without blockage the equilibrium outcome is export with $\mathrm{S}$ imitation if $0<k<k_{1}$, licensing if $k_{1}<k<\bar{k}^{N B}$, and the export monopoly if $\bar{k}^{N B}<k<1$. Note that the North import ban raises the lower critical level and reduces the higher critical level of Southern patent rights, shrinking the licensing range. Further, the $\mathrm{N}$ firm's profits are the same under either import policy for an IPR level higher than $\bar{k}^{N B}$. Otherwise the import ban favors $\mathrm{N}$ profits at any level of Southern patent strength.

\section{3d. A Note on Wage Impacts}

This is a partial-equilibrium model in which it is relatively straightforward to describe wage effects of IPR policy. ${ }^{15}$ Assume that labor is the only factor of production and is in fixed supply. Let $\alpha$ be the unit labor requirement for producing the good in the South, where $\alpha$ declines with $x$. As the entry mode changes from exports to licensing, the unit labor requirement decreases and total quantity produced by $\mathrm{S}$ goes up. The first effect reduces labor demand but the second increases it and the latter impact dominates under a sufficiently large increase in S market share. In the North the unit labor requirement does not change while total quantity produced falls in the shift from exporting to licensing, thereby reducing labor demand and the wage rate.

Once licensing is the equilibrium further strengthening of patent rights increases the $S$ firm's market share. The increase in quantity dominates the reduction in labor requirement

\footnotetext{
${ }^{14}$ The $\mathrm{N}$ profit level is constant under the imitation threat (low $k$ ) because a change in IPR does not affect relative marginal costs, though it does reduce $\mathrm{S}$ profit through higher imitation costs.

${ }^{15}$ The mathematical appendix demonstrates these results.
} 
under large market sizes, raising the Southern wage rate. Correspondingly, the North wage rate falls as more know-how is transferred. Finally, when IPR gets sufficiently strong that the $\mathrm{S}$ firm exits and $\mathrm{N}$ asserts a monopoly, the Southern (Northern) wage rate declines (rises).

\section{3e. Alternative Market Assumptions}

We offer brief comments on the robustness of our results to alternative market structures. ${ }^{16}$ First, suppose there are two $\mathrm{N}$ firms but one has a superior process technology. In this case the critical Southern patent value at which licensing is chosen becomes higher because the $\mathrm{S}$ firm has two technologies to imitate. Beyond this value the lower-cost $\mathrm{N}$ firm would undertake licensing and the extent of know-how transferred would rise with $k$. The marginal gain from licensing rises faster with $k$ because it steals profits from the higher-cost $\mathrm{N}$ firm, making it possible for a greater amount of know-how to be transferred.

Second, suppose there are two $\mathrm{S}$ firms to which the single $\mathrm{N}$ firm can license, giving it more bargaining power. Here the critical $k$ inducing licensing is smaller than in the benchmark case and more know-how is transferred at every level of IPR in the licensing range. These results hold also when there is free entry into imitation in the South but $\mathrm{N}$ can license to a single firm. In this case the number of S imitators falls with $k$ in the licensing range. Overall, our findings remain qualitatively intact with different numbers of firms engaging in quantity competition.

Finally, return to two firms and suppose $\mathrm{N}$ and $\mathrm{S}$ compete in prices. Here either successful imitation or licensing permits $\mathrm{S}$ to capture the full global market at a price just below $\mathrm{N}$ marginal cost. Again, a critical $k$ exists above which $\mathrm{N}$ will sacrifice its production to gain a share of higher licensing profits. Within the licensing range, increases in patent

\footnotetext{
${ }^{16}$ Each of these claims can be readily proven analytically.
} 
strength do not affect $\mathrm{S}$ exports or price. While this case is perhaps less interesting analytically, it is consistent with firms fully outsourcing their production.

\section{Welfare Impacts of Strengthened IPR}

Welfare calculations in this context are complex and, to save space, we simply overview the results here. ${ }^{17}$ We consider the range of $k$ in which there may be imitation or licensing because once IPR protection becomes sufficiently high that $\mathrm{N}$ is a monopolist, further increases are redundant.

For $0<k<k_{1}$, S competes through imitation. Here an increase in patent rights reduces Southern well-being, defined as local consumer surplus plus the S firm's production profit, by diminishing the latter. Upon reaching $k_{l}$ there is a discrete jump in Southern welfare because the decision to license generates a positive know-how transfer, reducing $\mathrm{S}$ marginal cost and expanding competition and consumer gains. Beyond this point, stronger patent rights have offsetting effects. First, this policy shift reduces technology-transfer costs and increases the proportion of know-how transferred under licensing. These impacts increase S's profit and expand consumer gains from greater competition, with these effects being larger under higher local absorptive capacity. Second, the higher imitation cost reduces the value of the S firm's outside option, decreasing its licensing profits. Southern welfare increases if the former effects dominate. In fact, this outcome pertains for a sufficiently small $\mathrm{N}$ bargaining share. In brief, for IPR reform to raise local welfare under licensing, S must have a relatively strong bargaining position. Similar analysis shows that Southern welfare increases unambiguously with a rise in local absorption capacity. Once the

\footnotetext{
${ }^{17}$ Again, these computations are available in the mathematical appendix.
} 
equilibrium regime becomes an $\mathrm{N}$ monopoly at the higher critical value of $k$ Southern welfare falls discretely to its lowest level and remains constant.

We can show further that Northern welfare rises with $k$ in the low range because that policy decreases the threat of imitation, raising $\mathrm{N}$ profits. Upon reaching the licensing equilibrium range, stronger patents both raise $\mathrm{N}$ profits and expand competition, increasing welfare. In the high range of $k$, where a monopoly is established, the impact depends on the net effect of higher $\mathrm{N}$ profits and lower consumer welfare. A specific result is that Northern welfare in the monopoly range exceeds that in the imitation range if market sizes are large.

Finally, global welfare rises with a stronger IPR regime in the South under licensing, so long as the condition in equation (8) holds. Recall that this condition requires the joint market size to be large and the difference in post-transfer $\mathrm{N}$ and $\mathrm{S}$ marginal costs to be high. The policy change decreases the technology-transfer cost and expands know-how transfers, thereby increasing competition and consumer welfare. These effects outweigh any reduction in global profits. An expansion in absorptive capacity also increases global welfare by shifting more production to the South where marginal cost is lower. When the full $\mathrm{N}$ monopoly is reached, however, global welfare is diminished in comparison with licensing. Thus, in this model full protection would not be globally optimal. ${ }^{18}$

A final note is that the welfare impacts of a Northern ban on imitative S imports vary by country. It reduces $\mathrm{S}$ profits under imitation and also diminishes the $\mathrm{S}$ firm's share of licensing profits. These factors dominate and Southern welfare is diminished by blocking throughout the range of $k$ before the full monopoly is established. In contrast, this ban tends to raise Northern welfare by raising profits in the imitation range and achieving a higher profit share in the licensing range.

\footnotetext{
${ }^{18}$ See Grossman and Lai (2004) for additional insights.
} 


\section{Adding Foreign Direct Investment}

We now incorporate a simple specification of FDI into the model to permit a third important form of technology transfer. Suppose that the $\mathrm{N}$ firm has the option of creating an S subsidiary at a cost of $g=\gamma+z(x)$. Here, $\gamma$ is the fixed cost of setting up a plant and transferring technology, while $z(x)$ is the variable transfer cost, which increases with the proportion of know-how transferred. Since the S subsidiary is fully owned by the N multinational firm, it has no incentive to imitate. However, the subsidiary faces imitation risk from a local firm at the same cost as above.

In this setup, assuming sufficient market sizes the $\mathrm{N}$ firm would transfer the full amount of know-how to its subsidiary. ${ }^{19}$ The essential reason is that under FDI all profits are returned to $\mathrm{N}$, rather than shared under licensing. Accordingly, $\mathrm{N}$ transfers its full know-how to achieve the maximum reduction in production cost. Thus, in any FDI equilibrium the transfer cost $g=\gamma+z(1)$ is constant and the marginal production cost of the S subsidiary firm becomes $c_{D D}=c_{S}-r(1, a)$. Indeed, under FDI the $\mathrm{N}$ firm exits production altogether and serves both markets from its subsidiary, another case of full offshoring.

Consider next the entry mode of the $\mathrm{N}$ firm. Compared to licensing it now has two possible reservation values in the bargaining game. If the FDI transfer cost is less than the difference between production profits under FDI and production profits under exports, $\mathrm{N}$ chooses total profits with the subsidiary $\left(\Pi_{D D}\right)$ as its reservation value. Otherwise it chooses profits under production at home and export. To summarize, FDI involves a fixed setup cost but transfers know-how fully and achieves lowest marginal cost, while facing imitation risk.

\footnotetext{
${ }^{19}$ This claim is proven in the mathematical appendix.
} 
Licensing incurs a technology-transfer cost and generates partial knowledge transfer but does not face imitation risk.

Working through the profit functions we find the following results. For sufficiently high investment costs the reservation option for $\mathrm{N}$ is exports with imitation. That is the equilibrium for $0<k<k_{1}$, with the remaining equilibria as patent rights are strengthened the same as those described earlier. For lower setup costs the equilibrium is FDI with imitation for $0<k<k_{D}$, where $k_{D}>k_{l}$, with licensing occurring at yet-stronger patent rights before the monopoly ensues.

In essence the results of this simple model may be characterized as follows. In countries where subsidiary setup costs are large and patent protection is weak, the $\mathrm{N}$ firm competes through exports and accepts the risk of local imitation. In this case a tighter patent regime diminishes S profits and Southern welfare. However, if these countries strengthen IPR they can induce a licensing equilibrium, which favors $\mathrm{S}$ licensee exports and likely expands welfare. Alternatively, countries with weak patents but lower subsidiary setup costs are more likely to attract FDI than $\mathrm{N}$ exports. Here, as IPR are strengthened the imitative $\mathrm{S}$ firm becomes a licensee and increases in $k$ again expand local exports and well-being. The shifts from trade to FDI to licensing at various configurations of setup costs and patent rights are reminiscent of the literature on internalization and IPR (Markusen 2001).

To complete the analysis, note that if the North government blocked imitative imports under FDI with imitation, the impact would be to raise even further the minimum Southern IPR level at which licensing occurs and a diminution in the latter country's welfare.

\section{Summary and Conclusions}


In this paper we developed a model of strategic competition to study the effects of stronger IPR protection in developing countries on their export performance, the mode of technology transfer and welfare. By reducing the Southern firm's marginal cost related to the degree of know-how absorbed, and also the cost of technology transfer, patent reforms could expand export opportunities. We found also that Southern welfare could rise with both IPR and absorptive capacity if $\mathrm{S}$ has relatively high bargaining power.

This model is stylized but offers insights into means by which policymakers in developing countries might fashion their reforms in intellectual property. Specifically, stronger patent rights and trade secrets are likely to expand exports and improve welfare if domestic firms gain a more advanced ability to absorb and implement available international technologies. A complementary policy is to reduce the costs of establishing a subsidiary.

\section{References}

Branstetter, Lee, Raymond Fisman, and C. Fritz Foley (2005). ”Do Stronger Intellectual Property Rights Increase Technology Transfer? Empirical Evidence from U.S. Firm-Level Panel Data." Quarterly Journal of Economics 121: 321-349.

Branstetter, Lee, Raymond Fisman, C. Fritz Foley, and Kamal Saggi (2007), "Intellectual Property Rights, Imitation and Foreign Direct Investment: Theory and Evidence," NBER Working Paper 13033.

Diallo, Barrou (2003). "Historical Perspectives on IP Protection for Software in Selected Countries Worldwide," World Patent Information 25: 19-25.

Ginarte, Juan C. and Walter G. Park (1997). "Determinants of Patent Rights: A CrossNational Study." Research Policy 26: 283-301.

Glass, Amy J. and Kamal Saggi (1999). "Intellectual Property Rights and Foreign Direct Investment, ”Journal of International Economics 56: 387-410.

Grossman, Gene M. and Edwin L. C. Lai (2004). "International Protection of Intellectual Property," American Economic Review 94: 1635-1653. 
Hasan, Rana and Raturi (2001). "Does Investing in Technology Affect Exports? Evidence from Indian Firms." East-West Center Working Paper 21, May 2001.

Helpman, Elhanan (1993). "Innovation, Imitation, and Intellectual Property Rights." Econometrica 61: 1247-1280.

Kumar, Nagesh and N. S. Siddharthan (1993). "Technology, Firm Size and Export Behavior in Developing Countries: The Case of Indian Enterprises." UNU/INTECH Working Paper No 9.

La Croix, Sumner J. and Akihiko Kawaura (1996). "Product Patent Reform and Its Impact on Korea's Pharmaceutical Industry.” International Economic Journal10: 109-124.

Lai, Edwin L. C. (1998). "International Intellectual Property Rights Protection and the Rate of Product Innovation.” Journal of Development Economics 55: 115-130.

Lai, Edwin L. C. and Larry D. Qiu (2004). "The North's Intellectual Property Rights Standard for the South?” Journal of International Economics 59: 183-209.

Markusen, James R. (2001). “Contracts, Intellectual Property Rights and Multinational Investment in Developing Countries," Journal of International Economics 53: 189-204.

Maskus, Keith E. (2004). “Encouraging Technology Transfer," report for UNCTAD/ICTSD Project on Intellectual Property Rights and Sustainable Development, Issue Paper no. 7.

Smith, Pamela J. (2001). "How Do Foreign Patent Rights Affect U.S. Exports, Affiliate Sales, and Licenses?" Journal of International Economics 55: 411-440.

Taylor, M. Scott (1994). “Trips, Trade, and Growth.” International Economic Review 35: 361-381.

U.S. Department of Commerce, Bureau of Economic Analysis (2007), U.S. International Services: Cross-Border Trade 1986-2006 and Sales through Affiliates 1986-2005, at http://www.bea.gov/international/intlserv.htm.

Vishwasrao, Sharmila (1994). "Intellectual Property Rights and the Mode of Technology Transfer.” Journal of Development Economics 44: 381-402.

Vishwasrao, Sharmila (2007). "Royalties versus Fees: How Do Firms Pay for Foreign Technology?” International Journal of Industrial Organization 25: 741-759.

Yang, Guifang and Keith E. Maskus (2001). "Intellectual Property Rights, Licensing, and Innovation in an Endogenous Product-Cycle Model." Journal of International Economics 53: 169-187. 
Figure 1. Northern Profits from Export and Licensing under North Free Imports and Blocked Imports

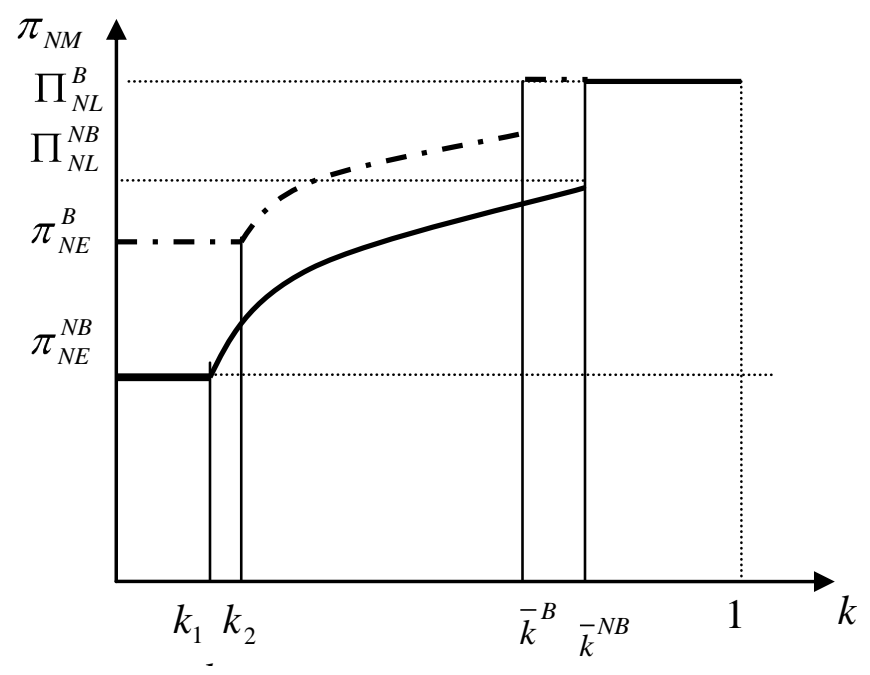

